\title{
Abbreviations
}

All ER All England Law Reports

Am.J.Comp.L. American Journal of Comparative Law

Amsterdam Treaty of Amsterdam amending the Treaty on European

Treaty Union, signed on October 2, 1997, and entered into force on May 1, 1999

CFI Court of First Instance

CFSP Common Foreign and Security Policy

CMLRev. Common Market Law Review

Colum.L.Rev. Columbia Law Review

Cornell Int.l. L.J. Cornell International Law Journal

Draft Draft Treaty Establishing a Constitution for Europe sub-

Constitution mitted to the European Council meeting in Thessaloniki on June 20, 2003

EAEC European Atomic Energy Community; also, when following number of treaty provision, Treaty Establishing the European Atomic Energy Community (Euratom), signed in Rome on March 25, 1957, and entered into force on January 1, 1958

EC European Community; also, when following number of treaty provision, European Community Treaty (formerly EEC Treaty; see EEC)

ECB European Central Bank

ECHR European Convention for the Protection of Human Rights and Fundamental Freedoms signed in Rome on November 4, 1950, and entered into force on September 3, 1953 
ECJ

ECLR

ECSC

ECtHR

EEC

EHRR

EJML

$E L J$

ELRev.

EP

$E P L$

ESCB

EU

European

Convention

Hast.L.J.

IGL

JEPP

JLS

JTDE

Maastricht

Treaty

MEP
European Court of Justice

European Competition Law Review

European Coal and Steel Community; also, when following number of treaty provision, Treaty Establishing the European Coal and Steel Community signed in Paris on April 18, 1951, entered into force on July 23, 1952, and expired on July 23, 2002

\section{European Court of Human Rights}

European Economic Community; also, when following number of treaty provision, Treaty Establishing the European Economic Community signed in Rome on March 25, 1957, and entered into force on January 1, 1958 (now EC Treaty, as renamed by the EU or Maastricht Treaty: see EC) European Human Rights Reports

European Journal of Migration and Law

European Law Journal

European Law Review

European Parliament

European Public Law

European System of Central Banks

European Union; also, when following number of treaty provision, European Union (or Maastricht) Treaty

The European Convention on the Future of Europe convened by the European Council meeting in Laeken, Belgium, on December 14-15, 2001

Hastings Law Journal

Intergovernmental Conference

Journal of European Public Policy

Journal of Law and Society

Journal des Tribunaux. Droit européen

Treaty of Maastricht, or European Union Treaty (see also EU), signed on February 7, 1992, and entered into force on November 1, 1993

Member of the European Parliament 
MJ

MP

NGO

Nice Treaty

NJB

NJW

OJ

$\mathrm{OMC}$

PJCC

PL

PM

QMV

$R D P$

RFDA

SEA

Stan.J.Int'l.L.

U.Ill.L.Rev.
Maastricht Journal of European and Comparative Law

Member of Parliament

Non-governmental Organization

Treaty of Nice amending the EU, EC, EAEC, and ECSC

Treaties, signed on February 26, 2001, and entered into force on February 1, 2003

Nederlands Juristenblad

Neue Juristische Wochenschrift

Official Journal of the European Communities

Open method of coordination

Police and Judicial Cooperation in Criminal Matters

Public Law

prime minister

qualified majority voting

Revue du Droit Public

Revue Française du Droit Administratif

Single European Act, signed on February 17, 1986, and entered into force on July 1, 1987

Stanford Journal of International Law

University of Illinois Law Review 
